\title{
Pengaruh Kualitas Pelayanan terhadap Kepuasan Wisatawan serta Dampaknya terhadap Loyalitas (Studi di Ciater Spa Resort)
}

\author{
Rahmat Priyanto ${ }^{1,}$ Hary Hermawan ${ }^{2,}$ Nurhalimah $^{3,}$ Suryana $^{4}$ \\ ${ }^{1,3,4}$ Universitas BSI Bandung, rahmat.rmp@,bsi.ac.id \\ ${ }^{2}$ STP AMPTA Yogyakarta, haryhermawan8@gmail.com
}

\begin{abstract}
The aim of this research is to know the influence of service quality to satisfaction and tourist loyality in Ciater Spa Resort. The method used in this research is descriptive verificative. Method analisis of this research is analisis path with software PLS. The results showed that the quality of service has no significant effect on loyalty, it means that service quality as exogenous variable requires intervening role (variable of satisfaction). Visitor satisfaction at Ciater Spa Resort has a significant effect on visitor loyalty. In addition, the relationship between the two research variables are positive, the increasing customer satisfaction will increase also loyalty, otherwise the decrease in visitor satisfaction will have an impact on the decrease in visitor loyalty. These findings have matched customer loyalty theory in marketing books. So that verifikatif research has been done successfully to verify the theory of loyalty in general. This article at once confirms a model of service theory as well as its relationship with satisfaction and loyalty, while minimizing the possibility of false loyalty so that this model can be used in the implementation of service management.
\end{abstract}

Keywords: service quality, satisfaction, loyality.

\begin{abstract}
ABSTRAK
Tujuan dari penelitian ini adalah untuk mengetahui pengaruh kualitas pelayanan terhadap kepuasan dan loyalitas wisatawan di Ciater Spa Resort. Penelitian ini berjenis deskriptif-verifikatif. Metode analisis yang digunakan adalah analisis jalur dengan alat bantu sofware Partial Least Square (PLS). Hasil penelitian menunjukan bahwa Kualitas pelayanan di Ciater Spa Resort tidak berpengaruh signifikan terhadap loyalitas, hal ini berarti bahwa kualitas pelayanan sebagai variabel eksogen membutuhkan peran intervening (variabel kepuasan). Sedangkan, kepuasan pengunjung di Ciater Spa Resort berpengaruh signifikan terhadap loyalitas pengunjung. Selain itu hubungan diantara kedua variabel penelitian tersebut adalah positif, maka semakin meningkatnya kepuasan pengunjung akan semakin meningkat pula loyalitasnya, sebaliknya semakin menurunya kepuasan pengunjung akan berdampak terhadap semakin menurunnya loyalitas pengunjung. Penemuan ini telah sesuai teori loyalitas pelanggan dalam buku-buku pemasaran. Sehingga penelitian verifikatif yang telah dilakukan berhasil memverivikasi teori loyalitas secara umum. Artikel ini sekaligus menegaskan sebuah model teori pelayanan serta hubunganya dengan kepuasan dan loyalitas, sekaligus mampu meminimalisir adanya kemungkinan loyalitas semu sehingga model ini dapat dipakai dalam implementasi manajemen pelayanan.
\end{abstract}

Kata Kunci: Kualitas Pelayanan, Kepuasan, dan Loyalitas. 


\section{PENDHULUAN}

Pariwisata merupakan adalah salah satu sektor industri andalan Indonesia. Sektor kepariwisataan memegang peranan penting dalam menumbuhkan perekonomian daerah, oleh karenanya mayoritas daerah di Indonesia bersaing dalam memperkenalkan potensi kepariwisataannya untuk menarik minat wisatawan berkunjung.

Potensi kepariwisataan di Provinsi Jawa Barat sangat banyak dan beragam. Selain itu, Jawa Barat memiliki berbagai macam destinasi wisata yang tersebar di masingmasing kabupaten. Keberadaan destinasi wisata tersebut berdampak pada tingkat kunjungan wisatawan domestik yang meningkat setiap tahunnya. Wisata alam menjadi jenis wisata yang paling banyak diminati (Brahmanto dkk., 2017).

Kabupaten Subang sebagai salah satu kabupaten di Jawa Barat yang memiliki banyak destinasi wisata yang cukup terkenal, salah satunya adalah Ciater Spa Resort. Melihat dari aktifitas promosi, Ciater Spa Resort merupakan salah satu destinasi paling diunggulkan oleh para pelaku wisata di Kabupaten Subang. Daya tarik yang ditawarkan Ciater Spa Resort adalah kolam rendam air panas. Selain itu, Ciater Spa Resort juga telah didukung beberapa fasilitas wisata lainnya yaitu : outbond activities, hotel and convention hall, restaurant and café, camping ground, beauty and wellness spa, rehabilition centre (fisiotherapy and hydrotherapy) dan lain sebagainya. Kelebihan dari Ciater Spa Resort adalah air panas alami yang berasal dari Pegunungan Tangkuban Perahu. Dengan keunggulan tersebut, pada saat ini banyak wisatawan yang berkunjung ke Ciater spa resort untuk menikmati kolam rendam air panas sekaligus berwisata di Ciater Spa Resort.

Fenomena di lapangan menunjukan indikasi bahwa wisatawan di Ciater Spa Resort tidak memiliki loyalitas tinggi. Hal ini terlihat dari data lapangan yang menunjukan bahwa mayoritas wisatawan baru datang untuk pertama kali, mengingat bahwa pembelian ulang atau dalam pariwisata berupa kunjungan ulang menjadi parameter tingkat loyalitas wisatawan (Kertajaya, 2013 dan Tjiptono, 2015). Diduga, wisatawan yang tidak datang kembali merupakan bentuk ketidakpuasan terhadap pelayanan yang dilakukan pengelola. Sehingga, ketidakpuasan tersebut berdampak pada keengganan wisatawan untuk berkunjung kembali ke Ciater Spa Resort.

Strategi bersaing pada bisnis pariwisata dewasa ini mutlak menuntut perhatian penuh para pengelola jasa pariwisata dalam mengelola kepuasan maupun ketidakpuasan. Pada dasarnya skema bisnis suatu perusahaan jasa wisata adalah menciptakan kepuasan pengunjung, dengan harapan wisatawan yang terpuaskan tersebut akan loyal, sehingga mampu memberi kontribusi keuntungan perusahaan yang berkelanjutan dalam jangka panjang. Banyak studi membuktikan bahwa semakin tinggi tingkat kepuasan akan semakin meningkat loyalitas wisatawan berkunjung ke destinasi (Hermawan, 2017b; Priyanto, 2016; Ihshani, 2005). Sehingga secara tidak langsung berkorelasi dengan tingkat keuntungan perusahaan, ketika pengunjung puas, maka mereka akan melakukan pembelian ulang pada produk yang ditawarkan perusahaan. Namun disisi lain, apabila tingkat kepuasan yang dirasakan pengunjung rendah, maka terdapat kemungkinan bahwa pengunjung tersebut akan berpindah ke layanan pesaing.

Salah satu upaya strategik dalam menjaga kepuasan dan loyalitas pelanggan dapat dilakukan dengan cara menjaga kualitas pelayanan. Kualitas pelayanan dapat diartikan sebagai tingkat kepuasan tamu atau konsumen. Tingkat kepuasan tamu diperoleh dari perbandingan pelayanan yang nyata di terima pengunjung, dengan nilai kualitas yang sebelumnya diharapkan. Sehingga asumsi umum akan belaku "pelayanan yang baik adalah adalah pelayanan yang sesuai dengan harapan konsumen" (Tjiptono, 2004).

Pariwisata sebagai bisnis jasa hospitality, maka kualitas pelayanan yang humanis menjadi kunci keberhasilan dalam memuaskan wisatawan (Hermawan, 2017a). 
Pelayanan yang berkualitas sangat menentukan keberhasilan bisnis pariwisata. Pelayanan berkualitas dapat diwujudkan melalui sumber daya manusia yang kompeten untuk mewujudkan nilai-nilai dalam pelayanan prima, serta didukung sarana prasarana atau fasilitas yang memadahi. Perpaduan kompetensi staf didukung sarana prasarana atau fasilitas yang baik diharapkan mampu mewujudkan pelayanan prima, yaitu pelayanan yang mampu memberikan nilai (value) positif yaitu terciptanya kepuasan wisatawan.

Oleh karena itu, artikel ini akan menggali sejauh mana loyalitas dan kepuasan wisatawan dapat diwujudkan dengan pelayanan prima yang dilakukan oleh pengelola Ciater Spa Resort, sebuah destinasi wisata di Kabupaten Subang, Jawa Barat.

\section{KAJIAN LITERATUR \\ Kualitas Pelayanan}

Goetsch dan

Davis

mendefinisikan kualitas sebagai " kondisi dinamis yang berhubungan dengan produk, jasa, sumber daya manusia, proses, dan lingkungan yang memenuhi atau melebihi harapan." Sementara itu, Kotler \& Makens (1999) mendifinisikan kualitas sebagai keseluruhan ciri serta sifat suatu produk atau pelayanan yang berpengaruh pada kemampuan untuk memuaskan kebutuhan yang dinyatakan atau yang tersirat.

Sedangkan pelayanan adalah kegiatan yang dapat diidentifikasi dan bersifat media penghubung antara satu pihak dengan pihak lain dengan maksud dan tujuan tertentu (Febriany, 2014).

Tjiptono dan Chandra (2011) menyatakan bahwa secara sederhana kualitas pelayanan adalah ukuran seberapa bagus tingkatan layanan yang diberikan mampu sesuai dengan ekspektasi pelanggan artinya kualitas pelayanan artinya kebutuhan dan keinginan tamu atau pengunjung yang di tentukan perusahaan.

Dalam bisnis pariwisata, pelayanan menjadi dasar dan motivasi utama dari usaha yang dijalankan. Semangat melayani dengan mengutamakan kebutuhan pelanggan harus dimiliki oleh seluruh jajaran staf tanpa pandang bulu, baik itu top manajer maupun staf operasional sesuai porsi dan uraian tugas masing-masing (Hermawan, 2017a).

Upaya mewujudkan pelayanan prima dapat dibangun dan diterapkan dengan menganut 5 dimensi pelayanan prima sebagai berikut : (1) Realibilitas (realibility), adalah kemampuan untuk memberikan secara tepat dan benar jenis pelayanan sesuai yang telah dijanjikan kepada pelanggan; (2) Responsif (Responsiveness), yaitu kesadaran atau keinginan untuk bertindak capat dalam membantu pelanggan dan memberikan pelayanan tepat waktu; (3) Kepastian/jaminan (Assurance), adalah pengetahuan dan kesopan santunan serta kepercayaan diri pegawai. Dimensi assurance memiliki ciri-ciri: kompetensi untuk memberikan pelayanan dan memiliki sifat respek kepada tamu; (4) Empati (Empathy), memberikan perhatian individu kepada tamu secara khusus. Dimensi empati memiliki ciri-ciri : kemauan untuk melakukan pendekatan, memberikan perlindungan, usaha untuk mengerti keinginan, kebutuhan dan perasaan tamu; (5) Pelayanan prima akan terwujud jika didukung oleh sarana prasarana yang berwujud nyata (tangible). Nyata (Tangibles) yaitu sesuatu yang nampak atau yang nyata yaitu : penampilan para pegawai yang rapi, fasilitas peralatan yang bersih dan higyene, peralatan fasilitas penunjang yang berfungsi baik dan lain sebagainya (Saleh \& Ryan, 1991 dan Hermawan, 2017a).

\section{Definisi Kepuasan}

Kepuasan wisatawan adalah tingkat perasaan seseorang setelah membandingkan kinerja atau hasil yang dirasakan dibandingkan dengan harapannya (Kotler dan Makens, 1999).

Dalam bukunya yang lain, Kotler (2002) mendefinisikan kepuasan sebagai perasaan senang atau kecewa seseorang yang muncul setelah membandingkan antara persepsi/ kesannya terhadap kinerja (atau hasil) suatu produk dan harapan-harapannya. Kepuasan tentang daya tarik wisata dibandingkan dengan harapan wisatawan 
sebelum berkunjung di daya tarik wisata tersebut.

Dalam bisnis pariwisata pelayanan terlihat sebagai salah satu varibel penentu kepuasan ; (Ihshani, 2005; Hamzah \& Hariyanto, 2015; dan Priyanto, 2016). Kepuasan pengunjung yaitu tingkat kepuasan seseorang setelah membandingkan kinerja produk yang dirasakan dengan harapannya, maka dalam menilai tingkat kepuasan dilakukan pengukuran antara kesesuaian harapan wisatawan dilayani dibandingkan dengan pelayanan nyata yang diberikan pengelola Ciater Spa Resort

\section{Definisi Loyalitas}

Secara umum, loyalitas dimaknai sebagai komitmen pelanggan untuk berlangganan atau membeli ulang produk/jasa terpilih secara konsisten (Hurriyati, 2005); (Selang, 2013); (Hasan, 2008). Dalam kajian pemasaran pariwisata, loyalitas yang dimaksud adalah kunjungan ulang ke sebuah destinasi wisata.

Definisi lebih spesifik dari loyalitas adalah sebuah kondisi dimana pelanggan mempunyai sikap positif terhadap suatu merk, mempunyai komitmen terhadap merk tersebut, dan bermaksud meneruskan pembeliannya dimasa mendatang. Ini berarti loyalitas selalu berkaitan dengan preferensi pelanggan dan pembelian aktual (Lupiyodi, 2013: 34).

Loyalitas pelanggan merupakan perilaku yang terkait dengan merek sebuah produk, termasuk kemungkinan memperbaharui kotrak merek di masa yang akan datang, berupa kemungkinan pelanggan merubah dukunganya terhadap merek, atau berupa kemungkinan pelanggan untuk meningkatkan citra positif suatu merek produk. Namun jika produk dianggap tidak memuaskan pelanggan, pelanggan akan bereaksi dengan cara exit (pelanggan menyatakan berhenti membeli merek atau produk) dan voice (pelanggan menyatakan ketidakpuasan secara langsung pada perusahaan) (Wallin Andreassen \& Lindestad, 1998).

Loyalitas pelanggan adalah merupakan efek akhir dari suatu pembelian, yang diartikan sebagai suatu sikap dan niat untuk berprilaku di masa depan, dan diekspresikan melalui komitmen untuk kembali membeli produk yang dibutuhkan pada perusahaan, komitmen untuk merekomendasikan kepada orang lain, niat atau keinginan untuk menceritakan hal positif mengenai perusahaan dan kesediaan untuk membayar mahal (Palitati, 2007). Sedangkan Kartajaya dan Setiawan (2014) menyatakan bahwa loyalitas tertinggi dilihat dari keaktifan pelanggan dalam merekomendasi brand (destinasi wisata).

Dari beberapa pendapat mengenai loyalitas pelanggan, dapat diambil kesimpulan bahwa loyalitas pelanggan adalah sikap positif yang ditunjukkan pelanggan terhadap suatu penyedia jasa dengan melakukan pembelian kembali produk atau jasa yang ditawarkan perusahaan dalam jangka panjang serta merekomendasikan perusahaan kepada kolega dan keluarganya.

Pemahaman loyalitas hanya pada indikator pembelian ulang dan rekomendasi terkadang tidak cukup, karena pelanggan yang membeli ulang dan menyebar berita belum tentu mempunyai sikap positif terhadap barang atau jasa yang di beli. Pembelian ulang tidak hanya terjadi karena puas, melainkan mungkin karena terpaksa atau suatu sebab lainya. Begitu juga tindakan menyebar berita mengenai suatu brand atau rekomendasi, rekomendasi juga bisa berupa rekomendasi negatif. Hal ini tidak termasuk dimensi loyalitas, melainkan hanya loyalitas semu/bias (Hermawan, 2017b dan Irawan, 2012).

Loyalitas pelanggan yang sejati dapat tercipta jika pelanggan menjadi pembela (advokat) bagi perusahaan tanpa insentif sekalipun (Selang, 2013). Maka dalam menghindari bias oleh loyalitas semu, dalam pencarian data ditekankan dengan pernyataan "dengan senang hati" sebagai bentuk ungkapan tanpa keterpaksaan.

\section{Hasil Penelitian Sebelumnya}

Hasil penelitian terdahulu membuktikan bahwa kualitas pelayanan sebagai faktor yang memperngaruhi kepuasan wisatawan (Ihshani, 2005; Hamzah \& Hariyanto, 2015; dan 
Priyanto, 2016). Kepuasan juga terbukti sebagai variabel yang berpengaruh terhadap loyalitas, sekaligus berperan sebagai variabel intervening penentu loyalitas, diantaranya penelitian Valle dkk (2006) dengan menggunakan metode Sturktur Equation Model (SEM), menemukan bahwa kepuasan berkontribusi positif terhadap loyalitas. Oleh karena itu, artikel ini mengkaji bagaimana hubungan dan pengaruh antara variabel kualitas pelayanan sebagai variabel eksogen, kepuasan sebagai variabel intervening dan loyalitas sebagai variabel engoden, yang diilustrasikan seperti tabel berikut

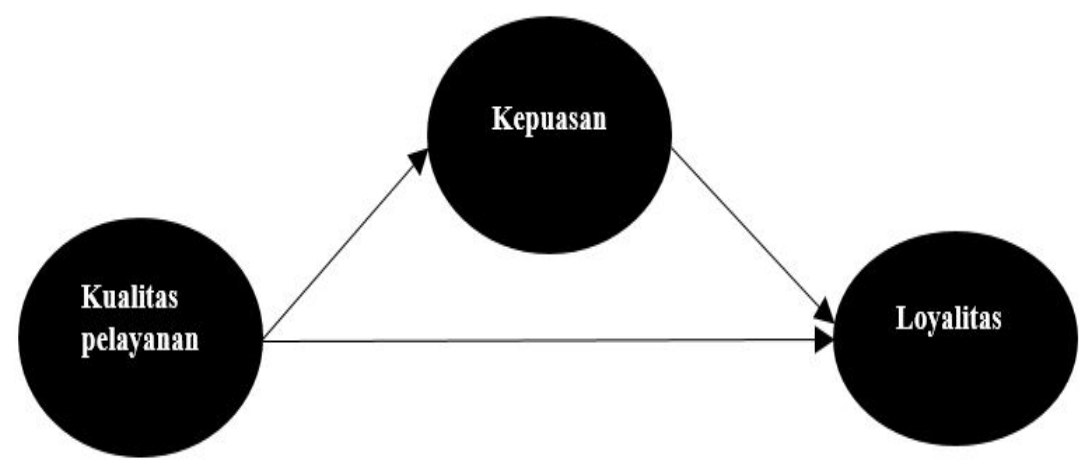

Gambar 1 : Kerangka Pemikiran

\section{METODE PENELITIAN}

Metode yang digunakan dalam mengkaji fenomena pengaruh kualitas pelayanan terhadap kepuasan dan loyalitas, dipilih metode deskriptif verifikatif dengan pendekatan analisis kuantitatif. Penelitian deskriptif adalah metode yang digunakan untuk menggambarkan atau menganalisis suatu hasil penelitian tetapi tidak digunakan untuk membuat kesimpulan yang lebih luas (Sugiyono, 2004).

Sedangkan verifikatif yaitu metode penelitian yang bertujuan untuk mengetahui hubungan antara dua variabel atau lebih. Metode ini juga digunakan untuk menguji kebenaran dari suatu hipotesis atau hasil penelitian yang telah dilakukan sebelumnya, terkait pengaruh atau bentuk hubungan kausal antara variabel $X$ (kualitas pelayanan) sebagai variabel eksogen, variabel Y1 (kepuasan) sebagai variabel intervening dan variabel (Y2) sebagai variabel endogen. Metode verifikatif dalam penelitian ini bertujuan untuk : (1) Menganalisis pengaruh variabel kualitas pelayanan terhadap variabel kepuasan Ciater Spa Resort; (2) Menganalisis pengaruh variabel kualitas pelayanan terhadap variabel loyalitas Wisatawan Ciater Spa Resort; (4) Menganalisis pengaruh variabel kepuasan terhadap loyalitas wisatawan Ciater Spa Resort.

Penelitian telah dilakukan di Ciater Spa Resort, Kabupaten Subang, Jawa Barat. Tehnik pencarian data digunakan adalah metode probaility sampling kepada 100 secara acak. Instrumen yang digunakan adalah angket dengan skala likert 1 sampai 5 untuk mengukur tingkat persetujuan terhadap peryataan yang diajukan peneliti. Alnalisis data menggunakan analisis jalur (path analisys) dengan alat bantu Sofware Partial Least Square (PLS) dengan pertimbangan akurasi hasil, tingkat kepraktisan penggunaan, serta kemudahan dalam interprestasi data.

\section{HASIL DAN PEMBAHASAN \\ Hasil Analisis Inferensial}

Tahap pertama dari analisis PLS adalah menguji validitas dan reliabilitas model yang meliputi: Convergent Validity, Discriminant Validity dan Composite Reliability.

Hasil Pengujian Outer Model 
Menurut Chin (1998) dalam Imam Ghozali (2006), tekhnik parametrik untuk menguji signifikan parameter dalam PLS tidak diperlukan, karena PLS tidak mengasumsikan adanya distribusi tertentu untuk estimasi parameter.

1. Validitas Konvergen (Convergent Validity)

Model pengukuran dengan refleksif indikator ditentukan berdasarkan korelasi antara item scorecomponent skor yang didestiminasi dengan software Partial Least Square (PLS). Convergent Validity diukur dari korelasi antara skor indikator dengan kosntruknya. Indikator individu Berdasarakan analisis outer loading (convergen validity) seperti pada tabel 1 diatas, dapat dilihat bahwa masing masing indikator dapat mencerminkan kunstuknya, meliputi : Variabel Kualitas pelayanan, kepuasan dan loyalitas. Hal ini dapat dibuktikan dengan nilai outer loading indikator yang disarankan semuanya memiliki nilai diatas 0,5 .

2. Validitas Diskriminan (Discriminant Validity)

Validitas diskriminan terjadi jika dua instrumen berbeda yang mengukur dua buah konstruk yang diprediksikan tidak berkorelasi menghasilkan skor-skor yang memang tidak berkorelasi (Ghozali, 2008 dan Gendro, 2011).

Suatu indikator dinyatakan valid jika mempunyai loading factor tertinggi kepada konstruk yang dituju dibandingkan loading factor kepada konstruk lain. Tabel $4.34 \mathrm{di}$ atas
Model pengukuran atau outer model dengan indikator reflektif dievaluasi dengan convergent validity dan discriminant validity dari indikatornya. Berikut hasil pengujian outer model untuk model struktural yang tersaji pada gambar dibawah ini:

dianggap valid jika memiliki nilai korelasi diatas $0,7(>0,7)$. Namun loading 0,50 sampai 0,60 masih dapat diterima dengan melihat output korelasi indikator dengan konstruknya (Ghozali, 2008 dan Gendro, 2011). Apabila ada indikator yang tidak memenuhi syarat ini maka tidak digunakan dalam anlisis selanjutnya.

menunjukkan bahwa loading factor untuk indikator X1 (x1.1 sampai dengan $\mathrm{x} 1.4$ ) mempunyai loading factor kepada konstruk x1 lebih tinggi dari pada dengan konstruk yang lain. Begitu pula kontruk-konstruk lain dengan indikatornya sendiri, masing-masing indikator memiliki loading factor kepada konstruknya yang lebih tinggi dari pada dengan konstruk yang lain. Lihat data yang ditulis tebal/bold pada tabel diatas. Dengan begitu maka dapat disimpulkan bahwa masingmasing indikator adalah valid, atau benar merupakan cerminan variabel atau konstruknya sendiri.

3. Reliabilitas Konstruk

Reliability blok indicator yang mengukur suatu kosntruk dapat dievaluasi dengan menggunakan output yang dihasilkan oleh $P L S$ pada tabel composite reliability seperti tabel dibawah ini :

Tabel 4.35

Composite Reliability

\begin{tabular}{|c|c|c|}
\hline Variabel & Reliability & Kriteria \\
\hline Kualitas Pelayanan (X) & 0.913 & Reliabel \\
\hline Kepuasan (Y1) & 0.914 & Reliabel \\
\hline Loyalitas (Y2) & 0.927 & Reliabel \\
\hline
\end{tabular}

Sumber: Data primer (2017) 
Hasil analisis menunjukkan bahwa Composite Reliability pada semua konstruk telah mempunyai nilai yang memuaskan, yaitu nilai masingmasing variabel diatas nilai minimum 0,60. Berdasarkan nilai tersebut

\section{Hasil Pengujian Inner Model}

1. Koefisien Determinasi $\left(\mathrm{R}^{2}\right)$

Analisis inferensial dilakukan berdasarkan hasil uji model struktural menunjukkan konsistensi dan stabilitas indikator yang digunakan tinggi. Berdasarkan penjelasan hasil analisis diatas dapat disimpulkan bahwa reliabilitas indikator masingmasing variabel terpenuhi.

(Inner Model), pada hasil output $R$ Square $\left(\mathrm{R}^{2}\right)$ sebagai berikut :

Tabel 4.36

Koefisien Determinasi $\left(\mathrm{R}^{2}\right)$

\begin{tabular}{|c|c|c|}
\hline Variabel & R Square & $\begin{array}{c}\text { R Square } \\
\text { Adjusted }\end{array}$ \\
\hline $\begin{array}{c}\text { Kepuasan } \\
\text { (y1) }\end{array}$ & 0.336 & 0.331 \\
\hline $\begin{array}{c}\text { Loyalitas } \\
\text { (y2) }\end{array}$ & 0.673 & 0.668 \\
\hline
\end{tabular}

Sumber: Data primer (2017)

Berdasarkan hasil analisis pada tabel 4.36, atau hasil uji Koefisien Determinasi $\left(\mathrm{R}^{2}\right)$ diketahui bahwa : (1) Variabel eksogen kualitas pelayanan $(\mathrm{X})$ mempengaruhi variabel kepuasan sebesar 0,331 atau 33,1\%. Sedangkan sisanya sebesar $67,9 \%$ lainya dipengaruhi oleh variabel selain variabel eksogen tersebut; (2) Variabel eksogen kualitas pelayanan (X) serta variabel intervening kepuasan (y1) bersama-sama mempengaruhi variabel endogen loyalitas (y2) sebesar 0,668 atau
$66,8 \%$. Sedangkan sisanya sebesar $44,2 \%$ lainya dipengaruhi oleh variabel selain ketiga variabel yang diteliti tersebut.

2. Analisis Jalur (Path Analisys)

Analisis jalur (path analisys) ditujukan untuk melakukan analisis terhadap model penelitian dari suatu diagram yang menghubungkan antara variabel-variabel independen (eksogen), intervening, dan variabel dependen (endogen) (Sarwono, 2007). Hasil analisis jalur penelitian disajikan seperti tabel berikut : 


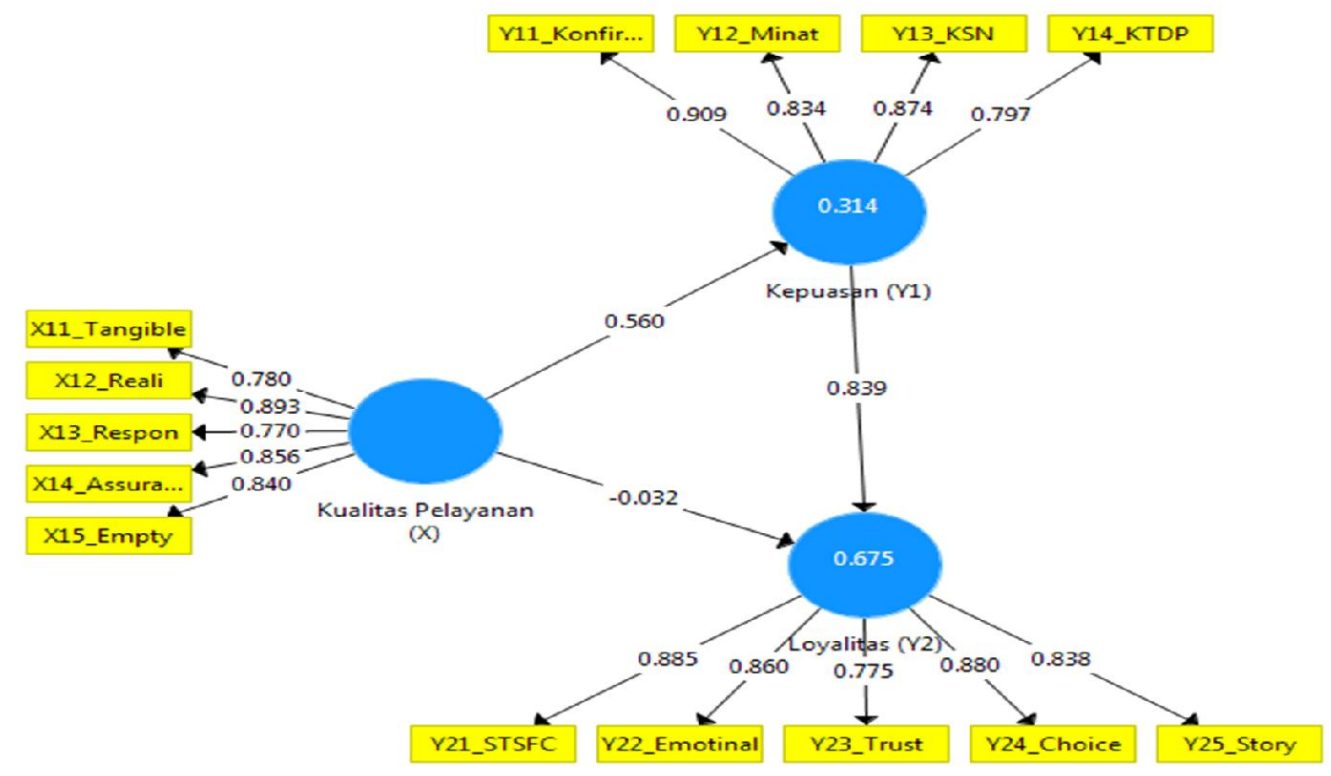

Gambar 2. Hasil Analisis Jalur

Sumber : data primer (2017)

Analisis jalur dilakukan dengan menghitung pengaruh langsung (Direct Effect), pengaruh tidak langsung (Indirect Effect), serta pengaruh totalnya (Total Effect) (Sarwono, 2007).

Berdasarkan koefisien jalur pada Tabel 4.20 diatas dapat di buat interprestasi sebagai berikut

a. Pengaruh Langsung

1) $\mathrm{X} \rightarrow \mathrm{Y} 1$, Pengaruh langsung variabel kualitas pelayanan terhadap kepuasan wisatawan 0,560 , atau sebesar $56 \%$. Berpengaruh postif serta terbukti signifikan.

2) Y1 $\longrightarrow 2$, Pengaruh langsung kepuasan terhadap loyalitas wisatawan sebesar 0,839 , atau sebesar $83,9 \%$. Berpengaruh positif serta terbukti signifikan pada taraf kepercayaan $95 \%$.

3) X1 $\rightarrow 2$, Pengaruh langsung variabel kualitas pelayanan terhadap loyalitas sebesar $-0,032$, atau sebesar $34,7 \%$. Berpengaruh negatif serta terbukti tidak signifikan pada taraf kepercayaan $95 \%$.

b. Pengaruh Tidak Langsung

Pengaruh tidak langsung dicari dengan cara mengalikan besarnya pengaruh langsung masing-masing variabel independent/ eksogen terhadap intervening, dengan besar pengaruh variabel intervening terhadap variabel dependent/ endogen seperti berikut :

1) $\mathrm{X} 1 \rightarrow 1 \quad \mathrm{Y} \rightarrow$ besarnya pengaruh tidak langsung antara variabel kualitas pelayanan terhadap loyalitas dengan intervening variabel kepuasan adalah 0,220 , atau sebesar $22 \%$. Dengan hubungan positif yang terbukti signifikan, karena $P$ value 0.000 jauh lebih kecil dari nilai alpha 0,05 pada taraf kepercayaan $95 \%$. Sedangkan variabel kepuasan berperan mengintervensi 0,539 atau sebesar 53,9\% dalam menentukan pengaruh daya tarik wisata terhadap loyalitas loyalitas wisatawan. 
2) Pengaruh Total

Nilai pengaruh total dicari dengan cara menjumlahkan besarnya pengaruh langsung masing-masing variabel independent/ eksogen terhadap variabel dependent/ endogen, dengan besarnya pengaruh tidak langsung (melewati intervening) dari masing-masing independent/ eksogen terhadap variabel dependent/ endogen, besarnya pengaruh total variabel kualitas pelayanan terhadap loyalitas dengan intervening variabel kepuasan adalah 0,567 , atau sebesar 56,7\%. Dengan hubungan positif yang terbukti signifikan, karena $P$ value 0.000 jauh lebih kecil dari nilai alpha 0,05 pada taraf kepercayaan $95 \%$. Sedangkan variabel kepuasan berperan mengintervensi 0,539 atau sebesar 53,9\% dalam menentukan pengaruh daya tarik wisata terhadap loyalitas wisatawan.

\section{Pembahasan}

Kualitas pelayanan di ciater spa resort terlihat memiliki penilaian baik, dimana dimensi assurance, reliability dan tangibles menjadi tiga dimensi dengan skor penilaian tertinggi. Pengunjung Ciater Spa Resort memiliki tingkat kepuasan sangat baik, dimana indikator pernyataan Y1 yaitu : keinginan untuk menyampaikan informasi positif kepada orang lain memiliki skor penilaian tertinggi. Pengunjung Ciater Spa Resort memiliki loyalitas baik, dimana indikator pernyataan Y2 yaitu : mengajak orang lain atau keluarga untuk berkunjung memiliki skor tinggi.

Kualitas pelayanan di Ciater Spa Resort berpengaruh signifikan terhadap kepuasan pengunjung penemuan ini mendukung penelitian sebelumnya (Ihshani, 2005; Hamzah \& Hariyanto, 2015; dan Priyanto, 2016). Selain itu korelasi hubungan diantara kedua variabel penelitian tersebut adalah positif, maka semakin baiknya kualitas pelayanan yang diberikan oleh pengelola Ciater Spa Resort maka akan semakin meningkat pula kepuasan pengunjungnya, sebaliknya semakin buruk kualitas pelayanan yang diberikan akan berdampak terhadap semakin rendahnya kepuasan pengunjung.

Kualitas pelayanan di Ciater Spa Resort tidak berpengaruh signifikan terhadap loyalitas, hal ini berarti bahwa kualitas pelayanan sebagai variabel eksogen membutuhkan peran intervening (variabel kepuasan). Sedangkan, kepuasan pengunjung di Ciater Spa Resort berpengaruh signifikan terhadap loyalitas pengunjung. Selain itu hubungan diantara kedua variabel penelitian tersebut adalah positif, maka semakin meningkatnya kepuasan pengunjung akan semakin meningkat pula loyalitasnya, sebaliknya semakin menurunya kepuasan pengunjung akan berdampak terhadap semakin menurunnya loyalitas pengunjung.

Penemuan ini telah sesuai teori loyalitas pelanggan dalam buku-buku pemasaran. Sehingga penelitian verifikatif yang telah dilakukan berhasil memverivikasi teori loyalitas secara umum. Artikel ini sekaligus menegaskan sebuah model teori pelayanan serta hubunganya dengan kepuasan dan loyalitas, sekaligus mampu meminimalisir adanya kemungkinan loyalitas semu sehingga model ini dapat dipakai dalam implementasi manajemen pelayanan.

\section{PENUTUP}

Kualitas pelayanan di Ciater Spa Resort berpengaruh signifikan terhadap kepuasan pengunjung penemuan ini mendukung penelitian sebelumnya (Ihshani, 2005; Hamzah \& Hariyanto, 2015; dan Priyanto, 2016). Selain itu korelasi hubungan diantara kedua variabel penelitian tersebut adalah positif, maka semakin baiknya kualitas pelayanan yang diberikan oleh pengelola Ciater Spa Resort maka akan semakin meningkat pula Kepuasan pengunjungnya, sebaliknya semakin buruk Kualitas pelayanan yang diberikan akan berdampak terhadap semakin rendahnya Kepuasan pengunjung. 
Kualitas pelayanan di Ciater Spa Resort tidak berpengaruh signifikan terhadap loyalitas, hal ini berarti bahwa kualitas pelayanan sebagai variabel eksogen membutuhkan peran intervening (variabel kepuasan). Sedangkan, kepuasan pengunjung di Ciater Spa Resort berpengaruh signifikan terhadap loyalitas pengunjung. Selain itu hubungan diantara kedua variabel penelitian tersebut adalah positif, maka semakin meningkatnya kepuasan pengunjung akan semakin meningkat pula loyalitasnya, sebaliknya semakin menurunya kepuasan pengunjung akan berdampak terhadap semakin menurunnya loyalitas pengunjung.

Penemuan ini telah sesuai teori loyalitas pelanggan dalam buku-buku pemasaran. Sehingga penelitian verifikatif yang telah dilakukan berhasil memverivikasi teori loyalitas secara umum. Artikel ini sekaligus menegaskan sebuah model teori pelayanan serta hubunganya dengan kepuasan dan loyalitas, sekaligus mampu meminimalisir adanya kemungkinan loyalitas semu sehingga model ini dapat dipakai dalam implementasi manajemen pelayanan.

Berdasarkan hasil dan pembahasan, artikel ini memberikan rekomendasi menajerial yang dapat digunakan diantaranya : (1) Indikator Kualitas pelayanan yang memiliki skor terendah adalah empaty yaitu tentang karyawan memperhatikan kebutuhan wisatawan dengan sungguh - sungguh. Dalam hal ini, Ciater Spa Resort disarankan untuk lebih memberi perhatian kepada wisatwan di Ciater Spa. Memperhatikan keinginan dan kebutuhan dilayani agar dapat dipenuhi, dan wisatawan lebih merasa nyaman; (2) Indikator kepuasan yang memiliki skor terendah adalah kesediaan. Dalam hal ini Ciater Spa Resort disarankan untuk lebih memperhatikan keinginan pengunjung, karena bila keinginan pengunjung terpenuhi di suatu destinasi wisata maka pengunjung akan bersedia menyampaikan informasi positif Ciater Spa Resort ke teman atau keluarga terdekat ataupun orang lain; (3) Indikator loyalitas pengunjung yang memiliki skor terendah adalah tentang Trust dalam hal ini Ciater Spa
Resort disarankan untuk lebih meningkatkan pelayanan yang memuaskan seperti tanggap terhadap kebutuhuan pengunjung karena ketika pengunjung merasa puas dengan pelayanan yang di berikan maka mereka akan loyal; (4) Kualitas pelayanan di Ciater Spa Resort sudah diakui oleh pengunjung. Namun tetap perlu memperhatikan kualitas pelayanan yang ada. Karena dengan kualitas pelayanan yang baik, maka akan mudah suatu produk tersebut dikenal dan tertanam dibenak kosumen atau dalam hal ini pengunjung destinasi wisata dan kualitas pelayanan juga merupakan salah satu faktor yang terhubung dengan kepuasan pengunjung. Salah satu cara untuk mempertahankan kepuasan pengujung yaitu dengan inovasi secara berkala tanpa menghilangkan ciri khas yang telah di miliki Ciater Spa Resort; (5) Untuk meningkatkan loyalitas Ciater Spa Resort di harapkan lebih mampu meningkatkan faktor - faktor lainnya selain kualitas pelayanan mulai dari fasilitas maupun daya tarik wisata seperti menambah fasilitas atau sarana rekreasi yang baru , sehingga loyalitas pengunjung pada Ciater Spa Resort akan meningkat; (6) Ciater Spa Resort diharapkan mempu mempertahankan kepuasan dari pelanggan dan loyalitas dari perusahaan atau pelanggan agar Ciater Spa resort bisa mempertahankan eksistansinya di dunia kepariwisataan.

\section{REFERENSI}

Brahmanto, E., Hermawan, H., \& Hamzah, F. (2017). Strategi Pengembangan Kampung Batu Malakasari sebagai Daya Tarik Wisata Minat Khusus. Inarxiv

Febriany, C. D. K. (2014). Pengaruh Kualitas Pelayanan dan Fasilitas terhadap Kepuasan Wisatawan di Cikole Jayagiri Resort Bandung. Universitas Pendidikan Indonesia.

Gendro, W. (2011). Merancang Penelitian Bisnis Dengan Alat Analisis SPSS 17.0 \& Smart PLS 2.0: Percetakan STIM YKPM. Yogyakarta: Percetakan STIM YKPM.

Ghozali, I. (2008). Structural Equation 
Modeling Metode Alternatif dengan

Partial Least Square. Semarang: Badan

Penerbit Universitas Diponegoro.

Goetsch, D. L., \& Davis, S. B. (2014).

Quality Management for Organizational

Excellence. Pearson Upper Saddle

River, NJ.

Hamzah, F., \& Hariyanto, O. I. B. (2015). Pengaruh Pelayanan Prima terhadap Loyalitas Tamu Menginap di Sumber Alam Resort Garut. Jurnal Pariwisata, 2(2), 89-97.

Hermawan, H. (2017a). Pengantar Manajemen Hospitality. Jawa Tengah: Penerbit NEM.

Hermawan, H. (2017b). Pengaruh Daya Tarik Wisata, Keselamatan dan Sarana Wisata Terhadap Kepuasan serta Dampaknya terhadap Loyalitas Wisatawan : Studi Community Based Tourism di Gunung Api Purba Nglanggeran. Wahana Informasi Pariwisata : Media Wisata, 15(1), 562-577.

Hurriyati, R. (2005). Bauran Pemasaran dan Loyalitas Pelanggan. Bandung: Alfabeta.

Ihshani, D. W. (2005). Analisis Kepuasan Konsumen Terhadap Atribut Wisata Cangkuang Garut, Jawa Barat. IPB (Bogor Agricultural University). Retrieved from http://repository.ipb.ac.id/handle/12345 $6789 / 11549$

Irawan, C. (2012). Secangkir Kopi untuk Sahabat Customer. Jakarta: Prima grafika.

Kertajaya, H. (2013). Tourism Marketing 3.0. Jakarta: PT Gramedia Pustaka Utama.

Kotler, P. (2002). Manajemen Pemasaran, terjemahan Hendra Teguh, edisi Millenium, cetakan pertama (1st ed.). Jakarta: Prenhalindo.

Kotler, P., \& Makens, J. C. (1999). Marketing for Hospitality and Tourism, 5/e. Pearson Education India.

Palitati, A. (2007). Pengaruh Nilai Pelanggan, Kepuasan terhadap Loyalitas Nasabah Tabungan Perbankan di Sulawesi Selatan.
Universitas Haluoleo Kendari, Sulawesi Selatan.

Priyanto, R. (2016). Pengaruh Kualitas Pelayanan terhadap Kepuasan dan Loyalitas Pengunjung Saung Angklung Udjo. Jurnal Pariwisata, 3(1), 29-40.

Saleh, F., \& Ryan, C. (1991). Analysing service quality in the hospitality industry using the SERVQUAL model. Service Industries Journal, 11(3), 324345.

Sarwono, J. (2007). Analisis jalur untuk riset bisnis dengan SPSS.

Selang, C. A. D. (2013). Bauran Pemasaran (Marketing Mix) Pengaruhnya Terhadap Loyalitas Konsumen pada Fresh Mart Bahu Mall Manado. Jurnal Riset Ekonomi, Manajemen Bisnis Dan Akuntansi, 1(3).

Sugiyono. (2004). Metode Penelitian Kombinasi. Bandung: CV Alfabeta.

Tjiptono, F. (2004). Kepuasan dalam Pelayanan. Jakarta: Salemba Empat.

Tjiptono, F. (2015). Strategi Pemasaran. Yogyakarta: Andi Offset.

Tjiptono, F., \& Chandra, G. (2011). Service, Quality and Satisfaction. Yogyakarta: Andi Offset.

Valle, P. O. do, Silva, J. A., Mendes, J., \& Guerreiro, M. (2006). Tourist Satisfaction and Destination Loyalty Intention: A Structural and Categorical Analysis. International Journal of Business Science and Applied Management, 1(1), 25-44. Retrieved from http://business-andmanagement.org/library/2006/1_1--2544--

Oom_do_Valle,Silva,Mendes, Guerreiro .pdf

Wallin Andreassen, T., \& Lindestad, B. (1998). Customer Loyalty and Complex Services: The Impact of Corporate Image on Quality, Customer Satisfaction And Loyalty for Customers With Varying Degrees of Service Expertise. International Journal of Service Industry Management, 9(1), 723. 



\section{Lampiran}

\section{Hasil Uji Validitas Diskriminan}

\begin{tabular}{|c|c|c|c|}
\hline & Kepuasan (Y1) & $\begin{array}{l}\text { Kualitas Pelayanan } \\
\text { (X) }\end{array}$ & Loyalitas (Y2) \\
\hline X11_Tangible & 0.383 & 0.780 & 0.312 \\
\hline X12_Reali & 0.543 & 0.893 & 0.404 \\
\hline X13_Respon & 0.328 & 0.770 & 0.248 \\
\hline X14_Assurance & 0.474 & 0.856 & 0.376 \\
\hline X15_Empty & 0.534 & 0.840 & 0.430 \\
\hline Y11_Konfirmasi & 0.909 & 0.556 & 0.787 \\
\hline Y12_Minat & 0.834 & 0.409 & 0.694 \\
\hline Y13_KSN & 0.874 & 0.469 & 0.701 \\
\hline Y14_KTDP & 0.797 & 0.471 & 0.611 \\
\hline Y21_STSFC & 0.734 & 0.384 & 0.885 \\
\hline Y22_Emotinal & 0.725 & 0.327 & 0.860 \\
\hline Y23_Trust & 0.548 & 0.350 & 0.775 \\
\hline Y24_Choice & 0.720 & 0.419 & 0.880 \\
\hline Y25_Story & 0.730 & 0.380 & 0.838 \\
\hline
\end{tabular}

Hasil Uji Validitas Konvergen

\begin{tabular}{|l|c|c|c|c|c|}
\hline \multicolumn{4}{|c|}{ Variabel laten } & $\begin{array}{c}\text { Kesimpula } \\
\text { n }\end{array}$ \\
\hline Indikator & Kode & X & y1 & Kes. \\
\hline Tangible & X1.1 & $\mathbf{0 , 7 8 0}$ & & & Valid \\
\hline $\begin{array}{l}\text { Realibilit } \\
\text { y }\end{array}$ & X1.2 & $\mathbf{0 , 8 9 3}$ & & & Valid \\
\hline $\begin{array}{l}\text { Responsi } \\
\text { nness }\end{array}$ & X1.3 & $\mathbf{0 , 7 7 0}$ & & & Valid \\
\hline $\begin{array}{l}\text { Assuranc } \\
\text { e }\end{array}$ & X1.4 & $\mathbf{0 , 8 5 6}$ & & & Valid \\
\hline Empathy & X1.5 & $\mathbf{0 , 8 4 0}$ & & & Valid \\
\hline $\begin{array}{l}\text { Konfirma } \\
\text { si }\end{array}$ & Y1.1 & & $\mathbf{0 , 9 0 9}$ & & Valid \\
\hline Minat & Y1.2 & & $\mathbf{0 , 8 3 4}$ & & Valid \\
\hline $\begin{array}{l}\text { Kesediaa } \\
\text { n }\end{array}$ & Y1.3 & & $\mathbf{0 , 8 7 4}$ & & Valid \\
\hline $\begin{array}{l}\text { Ketidakp } \\
\text { uasan }\end{array}$ & Y1.4 & & $\mathbf{0 , 7 9 7}$ & & Valid \\
\hline $\begin{array}{l}\text { Satisfacti } \\
\text { on }\end{array}$ & X3.1 & & & $\mathbf{0 , 8 8 5}$ & Valid \\
\hline $\begin{array}{l}\text { Emotiona } \\
\text { 1 }\end{array}$ & X3.2 & & & $\mathbf{0 , 8 6 0}$ & Valid \\
\hline Trust & X3.3 & & & $\mathbf{0 , 7 7 5}$ & Valid \\
\hline Choice & X3.4 & & $\mathbf{0 , 8 8 0}$ & Valid \\
\hline Story & X3.5 & & & $\mathbf{0 , 8 3 8}$ & Valid \\
\hline
\end{tabular}

